\title{
Oh Comrade, What Times those Were! History, Capital Punishment and the Urban Square
}

\begin{abstract}
From the perspective of traditional Western histories of the urban realm, public squares have been seen to represent a privileged site of urban containment expressive of a community’s highest values of individual freedom, social inclusion and cultural refinement. But such views can be misleading. For what is omitted from the scope of these conventional historical visions and their ideal and conforming subjects of public spatial discourse, is an entire array of other and darker narratives that equally speak of personal choice, collective participation and cultural value. Capital punishment reflects such an example, a practice that once comprised an integral part of the political, social and cultural landscape of a Western city's squares and streets. Drawing from Michel Foucault's Discipline and Punish and its implications on how we might begin to re-read the history of the urban square, the following seeks to explore those practices and modes of rationality that underpinned the once public spectacle of executions and torture as a vital condition of urban life. In particular, this discussion will question the assumptions of an historical tradition that continues to reduce our understanding of the city and its open spaces of public appearance and action to an idealistic and illusory reality of the urban realm and its narrow framing of collective conduct, necessity and significance.
\end{abstract}

\section{Introduction}

At ten o'clock in the morning on the $23^{\text {rd }}$ May 1498 in the Piazza della Signoria, the sentence of heresy condemning the priest Girolamo Savonarola and two close associates to be hung and then burnt 'so that their souls be entirely parted from their bodies' was read out before a large gathering of Florentine citizens (Villari, 1969, p. 404). These same citizens then watched as Savonarola and his companions, stripped of their outer garments 
and arms bound, were first hung from the gibbet until dead and then, whilst still hanging, their lifeless bodies consumed by fire.

"In a few hours they were burnt, their legs and arms gradually dropping off; part of their bodies remaining hanging to the chains, a quantity of stones was thrown to make them fall, as there was a fear of the people getting hold of them; and then the hangman and those whose business it was hacked down the post and burnt it to the ground, bringing a lot of brushwood and stirring up the fire over the dead bodies, so that the very last piece was consumed” (Eyewitness account to the execution of Savonarola, qtd. in Botticelli, 1993, p. 922).

In the same manner as Foucault's description of the amend honourable of Damiens (1991), the above starkly portrays a time in Europe when executions registered no alien presence within the urban terrains of the public sphere when, rationally and idealistically, they served the judicial and penal ends of state, and when those who attended did not turn away in outrage or disgust. On the other hand, for our age, urban squares such as the Piazza della Signoria represent sites of cultural pilgrimage par excellence: spaces preserved for audiences to pay homage to architectural forms such as the Palazzo Vecchio and Loggia dei Lanzi, or to applaud the sculptural genius of Ammanati's Fountain of Neptune, Cellini's Perseus and Medusa or Michelangelo's David. But where today we drink coffee and engage in leisurely activities, what is not celebrated within such a culturally-centric bastion of urban space or admired alongside its icons of refined heritage are reminders of the scaffold and gibbet on which Savonarola and his followers were hung, the flames that devoured their mortal remains, or the citizens who gathered to observe, be amused, procure the odd souvenir or even add fuel to the fire for in this context, as observed by Nietzsche (1994, p. 57), 'every virtue has its privileges, one being to deliver its own little bundle of wood to the funeral pyre of a condemned man'.

To understand fully the historical conditions of the urban realm is to comprehend how individuals perceived and inhabited the urban environments of their own time, of the 
constellations of thought and rationality that informed and empowered the past realities of urban life. And yet, in relation to what the present conceives as a cherished site of urban and social necessity, of the many virtues and ideals attributed to the historical subject of the public square, the violence and norms of communal executions fail to appear as either a morally worthy or idyllic figure of urban existence. What this suggests is a fundamental disjunction between how the present perceives the past. But why? Is this a result of the present simply forgetting what once comprised a highly visible and vital aspect of European collective life? Or has it succumbed to an historical gaze that is less sincere, more selective and sanitized? What is certain is that through the normative lens of Western urban history we are offered a reading of urban squares that are seen to trans-historically extol the political and cultural merits of the ancient Greek polis and agora (Arendt, 1958; Jenks and Valentine, 1987) or of the Renaissance piazza and its wealth of civic festivals, celebrations, state proceedings and proclamations of law (Sitte, 1986). This is a history that venerates what Rowe and Koetter (1976) referred to as the traditions and virtues of communal life and decorum, or Winner (1992) of those conditions that nurture and represent individual expression, democratic participation and egalitarianism. What, nevertheless, remains obscured from all such narratives that pronounce on the earlier historical and public constituents of urban squares is an intense order of language, signs and practices that bound spectators to spectacle and which rendered death a legible and rational method of legal and religious atonement before retreating from the collective domains of cities, over the course of the nineteenth century, behind the closed walls of prisons.

This particular question of historical omission will not, however, be found from any limitations of knowledge or evidence that death, as an outcome of ritual torture and execution, fails to appear as a subject of our past understanding of various public arenas of urban space. Rather, this is suggestive of an idealized historical conception of such space that can be said, drawing from Nietzsche (1994), to have resulted from a contrived predominance of certain characteristics and withdrawal from view of others that would, if left in place, detract from the desired nature of that past vision. Bourdieu (1995) saw this issue of separation in the terms of divorcing any given subject of historical view away from 
its own contextual conditions of possibility or, more bluntly, by allowing the obsessions of nostalgia, trans-historical essences and fetishism to intrude between the historicity of a thing, leading towards the manufacture of an illusory subject of historical knowledge. What should also be added to this is the danger of then applying that same invention as a model to gauge the current state of any given subject, only to conclude that the present is lacking something or in decline when it fails to measure up against the ideals of that contrived figure of the past. We should, as a consequence, treat with caution claims that condemn the present when based on such historical constructions. Certainly this can be seen in relation to Richard Sennett who in The Fall of Public Man, like Arendt (1958) and Habermas (1992) before him, predicts the coming demise of the public realm. And equally like Habermas (1992, pp. 29-32), one frame of historical reference Sennett uses to support this concerned the eighteenth century English coffee shop as an exemplar of now lost egalitarian space (1993, pp. 81-82). But the public realm of the eighteenth century was a social and urban construct specific to the 'civil' or 'polite' society of the nobility and gentry. The urban geography and social interaction of this sphere did not extend to the vast majority of a population lacking the privileges of leisure, education or class (Basson, 1998). Coffee shops as a mirror of these same formations of social exclusion were also unwelcome to women. On the other hand, it is outside of Sennett's and indeed Habermas' coffee shop domain that vastly larger crowds assembled for the collective entertainment of capital punishment: gatherings that were inclusive of all genders, ages and classes. Another example for Sennett focused on Savonarola, the 'priest of the streets' (1993, pp. 232-6). But whilst promoting the power of his oratory and political and spatial interaction with the citizens of Florence, no mention is made of his fate or the part those same citizens played as audience during his execution. To refer in these terms to the 'fall of public man' is to indulge in a game of historical exclusion that removes from recognition what is inconvenient or disturbing. By truncating from the perception of urban history the once public rituals of penal ceremony, is also to engage in an ongoing programme of predominances, fetish and denial that supports a distorted sense of the historically acceptable, true and visible. 
To speak historically of public judicial executions as a rational discourse of necessity is also reminiscent of the themes contained in Foucault's Discipline and Punish. The primary focus of this, however, was concerned with the transition of penal discourse and practices from those centring on the body as site of punishment towards later strategies of incarceration and self-disciplinarity that concentrated on reforming the minds and behaviour of individuals. Whilst revisiting and building directly on this background, what is important for the following discussion is what is implied by Discipline and Punish and its framing of a particular dislocated historical perspective concerned with the social, cultural and political identity of the urban square. For this discussion, what Foucault and indeed the earlier works of Nietzsche, Kafka and Camus represent, is a counter discourse that has been present for over a century and yet remains unrecognized in terms of an historical tradition that continues to treat the urban square as a continuous and immutable expression of socially humane, culturally benign and politically liberating values. And, by so doing, render an entire history of human life expunged through the violence of the stake, garrotte or gallows an unsuitable and estranged subject of either historical acclaim or those ideals believed intrinsic to the life and meaning of the urban square.

What is raised here is a fundamental question on how we critically engage with the past constituents and contextual realities of the urban realm and how this impacts upon our current understanding, design and planning of public space. But such a question will not be addressed by maintaining allegiance to any universal conception of urban significance and norms of collective behaviour and rationality, or by arrogantly condemning, erasing or replacing what doesn't historically fit with the constructed standards of conduct, morality and activity applied to the urban environments of the present. Instead we must begin to contest an entire model of urban history that has allowed memory to give way to contemporary desire and a thirst for good and evil. Here we must resist the deployment of history as an instrument to escape from what human society is capable and in particular, to deny what has always been present through the introduction of urban myths that promote a highly censored and narrowly framed reading of the urban square. It is these questions of 
historical perception, interpretation and judgement that will be discussed around the subject of a time and mode of urban space and life when enforced death was a public affair.

\section{Distinctions of Time, Place and the Macabre}

Philip Aries once observed that 'everything in town goes on as if nobody died anymore' (1981, p. 56). But then today, the material presence of death exists only on the peripheries of our everyday urban experiences within architectural enclosures and geographical regions specific to the constituencies of the old, infirm, or demised. Emptied of what Camus (2000) described as the hideous signatures of our mortal ends, of what repels us and has to be conquered, the public spaces of the present have come to celebrate, amongst other things, the rights and values of life. Death plays no part in this, comprising instead a counter-realm of personal ceremony and grief, of perhaps medical and scientific failure, and of the dark resting places of Foucault's 'other city' (1985). Yet, in the earlier ages of Europe, the dead were not discreetly transported to distant cemeteries but openly acknowledged, displayed and memorialized in the streets and squares of cities: a feature that for some state funerals extended to the ceremonial parading of the exposed corpse as in the case of Marat or the disinterred body of Voltaire (Baecque, 2001). Today, even at funerals such as that of Diana, Princess of Wales, the bodies of the dead are firmly sealed in their caskets. But it is not

only these funereal images of death that have largely vanished from the public regions of the urban realm. What has also faded from visible and ethical sight is a range of collective rituals that centred on the premeditated cessation of life. At one level this would have included events like the Midsummer's Day celebrations in sixteenth-century Paris where, amidst the playing of solemn music, up to as many as two dozen cats suspended from a scaffold in sacks and baskets were burnt alive, and where the surrounding crowd revelled in the caterwauling of the creatures as their containers began to smoulder, prior to falling into the fire (Elias, 1978). At another level, this would have concerned the practice and drama of public executions. 
It was this particular question of urban, social and moral decline of capital punishment as an acceptable public activity that was captured in Kafka's short essay In the Penal Colony (1995). Here, Kafka introduced us to the chilling nature of a machine that combined the functions of scaffold, the implements of torture and death, and the role of executioner. These components were characterized as the 'bed', the part upon which the body of the condemned was placed; the 'harrow' which over a period of twelve hours terminally inscribed into the body of the victim a text spelling out the crime that had been transgressed; and the 'designer' which controlled and guided the operation of the 'harrow'. It was the decorative and overly embellished quality of the punitive script and the simplicity and precision of the apparatus that the officer in charge of the execution proudly described to the 'voyager', a visitor to the scene who had difficulty in either reading the text or appreciating the punitive character of the performance. In the presence of a single guard, the condemned soldier and the 'voyager', the officer admitted how there were now no longer any supporters of this type of execution left within the colony apart from himself, the sole defender of its legacy. He further lamented on how different it had once been, when the site of punishment had been overflowing with people who came to watch including the old commandant, ladies and high officials. On such days, the officer remarked, "It was impossible to grant every request to watch from close up. The commandant in his wisdom decreed that the children should be given priority; of course I myself, by virtue of my office, could always be close at hand; often I would be squatting there with a small child in either arm. How we all drank in the transfigured look on the tortured face, how we bathed our cheeks in the glow of this justice, finally achieved and soon fading! O comrade, what times those were!” (1995, p. 36).

What Kafka's narrative brought into view was a vanishing semiology on crime and punishment that was once both obvious and appealing to the European audiences of public executions. In this allegory on the legibility and idealization of punitive judgements, the officer represented the last member of a community - the penal colony - who in past times were fully conversant with the meanings attached to the language, aesthetics and purpose of the apparatus as it performed its prolonged judicial function upon the bodies of condemned 
criminals. Here, the truth of justice was displayed through the sublime synthesis of the crime, offender and sentence, a feat that was achieved through the punitive engraving of a script describing the crime upon the body of each criminal. On the other hand, the 'voyager' is a visitor who can be said to have travelled from our world. He is able to neither interpret nor decipher the text of the 'designer', nor to discern the 'beauty' of the overall process. The script, so clear to the officer, presents only a mass of confused lines, and the apparatus a mechanism not of truth, but of brutal and inhuman death and certainly no subject of public ceremony and glorification. Kafka also illustrated what would no longer predominantly be found in the centre of any urban terrain, a practice spatially displaced from squares and streets to the interior of prisons or to distant locations such as his island, where even there, this last vestige of an older world and site, ceremony and mechanism of human dispatch comprised an isolated and unfrequented arena of once collective activity. Through the antithetical figures of the 'voyager' and 'officer', Kafka exposed the gulf that separates such scenes from what has come to count as the rational and normalized conditions of our urban spaces of public appearance and through this, by extension, a profound moment of spatial, social and indeed historical dislocation. In particular, what is framed here is the disjunction in the nature of our contemporary expectations and conditions of legibility that, as observed by Camus in relation to the guillotine, 'if people are shown the machine, made to touch the wood and steel and to hear the sound of the head falling, the public imagination, suddenly awakened, will repudiate both the vocabulary and the penalty’ (1963, p. 128).

\section{Collective Theatres of Punishment}

It was the same competing states of sensibility exposed by Kafka through the vocabulary and penalty of his fiendish machine that Foucault would revisit later in relation to the amende honorable of Robert-Francois Damiens in 1757. But unlike Kafka’s allegorical portrayal, in Discipline and Punish (1991) Foucault mercilessly plunges us into the

disturbing and protracted stages of a punitive ceremony particular to the mid-eighteenth century city of Paris as an overture to an analysis of transitions in penal discourse, criminal 
deterrence and social control: an event whose prosecution along the streets leading to and within the Place de Greve included for the condemned the torments of torn flesh, red hot pincers, molten lead, boiling oil, dismemberment and burning. And yet, what is important for the historicity of this spectacle is that, despite the mode of execution and largely enthusiastic crowd, this did not represent any urban locus of collective appearance and performance dedicated to irrational and arbitrary acts of torture or any sadistic assembly of Parisians. What unfolded across the Place de Greve for the various participants of this state sponsored ritual, as with those of old in Kafka's colony, was a logic of punishment whose complexity and duration disclosed a measured and proportional response to the perceived magnitude and specificity of the crime. Today, the Place de Greve stands denuded not only of occupants who would appreciate the rationale and proportion of this execution, but also of its own name. Reincarnated as the Place de l'Hotel de Ville, this square has transformed into an urban site expressive of the culture of museums, the social leisure of markets and the political ideals of democracy as symbolized through the Paris mayoral offices of the Hotel de Ville. For the scope and rigour of history, however, such absences are problematic and if retained, merely serve to reinforce the naive certainty that no such exhibition of capital punishment could ever have reflected a free, popular or normal activity of urban life or are consistent with the values attributed to the idealized Western subject of public squares.

Nevertheless, the practice of legal redress through the choreographed violence of public executions represented their own idealized participatory drama that freely attracted audiences rather than repelled them. Part of this concerned their ability to provide a legible narrative from which, as Foucault observed (1991, p. 46), spectators 'could decipher crime and innocence, the past and the future, the here below and the eternal'. In an age when death promised not so much an end as a beginning, one feature of this narrative concerned the Christian themes of sin, redemption, heaven, divine judgement, and trials-by-ordeal. It is thus from the perspective of Christian transgression, contrition and forgiveness that the urban theatre of capital punishment could be read as a trial for the soul of the condemned. It was just such a trial and ordeal that Foucault emphasized through the multiple tortures and 
death of Damiens. For such a trial, by admitting guilt, asking forgiveness and accepting the many physical tortures of the body with piety, both atonement and heaven could be achieved. On the other hand, born of a religious ideology that sought to exchange a fear of death for a loss of eternal salvation, the most severe form of punishment concerned not the level of physical torture employed, but the loss of divine forgiveness via the denial of an attending priest: a situation that applied, for instance, to those found guilty of damaging Britain's waterways during the eighteenth century who would suffer death 'without the benefit of clergy' (Wood, 1969, p. 369). At the same time, it was this discourse on the hereafter that supported the rationality of taking life, at least to the extent that death was conceived as a transitional phase to another mode of existence or, as put by Camus (1963, p. 159), 'capital punishment is for the believer a temporary penalty that leaves the final sentence in suspense, an arrangement necessary only for terrestrial order, an administrative measure which, far from finishing off the guilty man, may instead favour his redemption'. From a religious perspective, what was acted out through these urban pageants of pain were the signatures of a strange and contrived martyrdom that recreated around the physical indignities and demise of the body, an idealized image of salvation and triumph over suffering by death in terms of a 'God humiliated, even to the death on the cross' and a 'Messiah triumphal over death by his own death' (Pascal, 1989, p. 239).

From the language of divine forgiveness and damnation, executions also communicated to their viewers the truth of any given crime. The nature of this reality, as Foucault made clear in Discipline and Punish, was composed not so much around the punishment fitting the offence as a replication of the crime upon the body of the perpetrator. What was, therefore, unveiled before audiences was an exemplary display that made manifest the authority and harsh justice of the state upon those who had offended its laws through a penal ceremony that portrayed the individuated characteristics and specificity of each crime. It is in these terms that the urban square transformed into a terrible theatre of justice where the performance of offence, offender and penalty were played out before spectators well versed in the stages and vocabulary of a drama that would always culminate with the demise of its leading character. Damiens was just such a leading player who personified through his 
ordeal the veracity of his guilt, the enormity of his crime - the attempted murder of Louis $\mathrm{XV}$, and the identity of his offence rendered apparent through acts such as the burning of sulphur upon the hand that held the knife. Here, justice was made visible before a crowd who acted out their own necessary and legitimating function as witness to the legality and prosecution of the verdict. The complexity and language of such penal ceremonies, however, were not only reserved for regicides. In Amsterdam in 1660 (Spierenburg, 1984), a male was condemned to death for the murder of an individual killed by being hit twice upon the head with an iron spade. For the condemned, his execution included being struck twice upon the head with the same spade before being garrotted and the spade laid next to his exposed corpse. Eighty-six years later in the same city, a woman was subjected to being broken on the wheel and throat slit. Her head, right hand and lower legs were then cut off. The crime expressed here had been the murder of her mistress and another servant for money and the subsequent dismembering of the servant and depositing of the pieces into various canals in order throw suspicion onto the missing servant girl for the crime.

But of primary importance for the rationalization of public torture and execution in the West was the concept of deterrence. Here, the exemplary nature of such violence and dispatch read as an educative practice and instrument of criminal prevention. The premise on which this extreme mode of instruction rested as Camus noted (1963, p. 136), was on an assumed fear of death. Additionally, the particular and protracted methods of torture deployed prior to death, would also have played a role in reinforcing the lesson. It was nonetheless, as a function of deterrence that the urban square transposed into an indispensable tool of this crude strategy of power and behavioural control. For it was generally, only in such locations that large crowds could gather. More especially, squares acted to channel and contain the very audience of spectators to whom these pedagogic measures of capital punishment were directed. It is then in the sense of a penal memento mori, that public squares on such occasions represented an urban lens that concentrated and magnified the attention of crowds toward what would await them should they follow in the footsteps of the condemned. Writing at the beginning of the nineteenth century, it was this same question of deterrence that led Jeremy Bentham (1882) to proclaim that capital 
punishments had become tame and objects of buffoonery lacking all respect. His suggested answer to this was to drape the scaffold in black, dress the officers of justice in mourning, place emblems of the crime upon the heads of the condemned, and play grave, religious music in order to more deeply impress the importance of the punishment upon the imagination of spectators. But by this time, the age of public executions was already in decline.

There was a time when the themes of crime and punishment, sin and redemption, truth and justice, deterrence and societal control empowered a rational and idealized discourse on torture and death performed as a collective practice of execution within the urban squares of the West. Today, the language inscribed into these punitive spectacles of the body and soul has disappeared. Left in their place is an incomprehensible and irrational pageantry of rituals and symbols that we, like Kafka's voyager, find difficult to interpret or desire as a suitable subject of our collective urban domains. But what has also disappeared with the vocabulary and physical presence of these penal ceremonies is an historical recognition of a now obscure urban geography of squares and streets that both framed and enhanced these sad performances of human demise that were once so familiar to spectator and condemned alike.

\section{Out of Sight and Mind}

Between the years of 1850 and 1870, in countries such as the German states, Netherlands, Britain, Austria and Spain (Spierenburg, 1984), the collective spectacle of executions ceased and with them departed a ceremony that for centuries had actively invested the urban realm, its squares and associated modes of social participation, religious belief and judicial procedure. The reasons behind this were many and varied. One aspect of this, as charted by Norbert Elias in The Civilizing Process (1978), spoke of transitions in sensibility and 'civilized' conceptions of society that realigned the period's standards of morality, refined behaviour and cultural pursuits. Another lay with the introduction during the nineteenth century of various governmental strategies of policing and deterrence that 
focused upon more widely dispersed and individuated mechanisms of behavioural and societal control, rendering the collective experience of capital punishments superfluous (Basson, 1998). As a result, punitive ceremonies began to be seen as ineffective tools of prevention that were both infrequent and incapable of ever impacting on anything other than a small proportion of any given population to which end, the urban square become redundant as an effective tool of punitive instruction. As a mechanism of criminal deterrence, public executions had also become counter productive to the extent that they had themselves become catalysts for civil unrest and violence by crowds who increasingly began to question the guilt of the condemned or identify with them as victims of unwarranted brutality. But to speak of reversals in sentiment and the adoption of wider systems of social regulation is also to touch upon, as indicated by Spierenburg (1984), changes associated not so much with the infliction of pain and suffering as with attitudes towards death.

'If the idea of God falls away, so does the feeling of 'sin' as a transgression against divine precepts’ (Nietzsche, 1994, p. 93). What also falls away is confidence in an immortal life and with it, the old certainties of punitive termination around what might constitute the removal of an individual's 'only' life. Doubts such as these began to develop over the course of the eighteenth century through discourse that advanced the rights, equality, values and welfare of humanity and the life of citizens. On the subject of executions, this brought into being critiques against the rights of the state to put to death any person whom it could leave alive without endangering the community 'even for the sake of making an example' (Rousseau, 1968, p. 23). Further limits on the judicial taking of life were expressed in relation to the establishment of guilt that relied on the use of questionable evidence or pain of torture to justify a death sentence (Louis Chevalier de Jaucourt in Diderot, 1967, pp. 211-212). What such questions demonstrated was that the nature of human life and its 'sanctity', from an 'enlightened' perspective, had changed. Death was no longer being conceived of as a beginning, but an end. Equally, in the terms of human perfectibility, the legitimacy of a Christianized regime of permanent guilt and inherent sin that Kafka identified with the realm of his 'penal' colony had passed. It was as a consequence of this 
shift in the idea, value and equity of life that enabled Thomas Paine (1996, p. 24), during the latter stages of the eighteenth century, to describe public executions as a false method for governing individuals, an instrument of terror that destroyed tenderness, corrupted mankind and excited revenge, and as a system that wasted life and disproportionately sent the poor to the scaffold.

Through discourse that privileged the status of human life and gave rise to new forms of cultural sentiment and structures of social governance, the nineteenth century saw public displays of torture and execution disappear from the streets and squares of cities as they reconfigured into rituals synonymous with cruel and inhumane treatment, indiscriminate deployment, and the irreversible presence of death. What also faded with this transformation was the urban and historical specificity of that past. Such was the fate of the Place de l'Hotel de Ville and indeed of the Place de la Concorde, which no longer invokes the urban qualities that favoured its use as a spatial theatre of the 'terror' and guillotine. In Rome, the Piazza Navona and Piazza del Popolo (Gross, 1990) stand mute as urban arenas of capital punishment. For London's once principal location of execution all that remains of the site and activities of the Tyburn gallows, as celebrated in Hogarth's The Idle 'Prentice Executed at Tyburn (1747), are brass markers identifying where the gallows posts stood surrounded by the exclusive town houses of Connaught Square. And yet, even if such traces are read or such practices remembered at all, such a past is marginalized as an aberration of urban life and public expression, never its norm.

But this rupture from one reality and experience of the urban square to another should not be confused with any question of outright progress in the sense of the human or social condition. Capital punishments did not cease with their departure from the public gaze: safely hidden from the collective view and sensibilities of society, condemned prisoners, caged and isolated, have still to psychologically await and confront the terror of their own particular trial and ordeal of 'humane' extinction. Just as capital punishments have not come to an end, the judicial use of torture also continues. This has perhaps most recently been demonstrated by US and British military authorities in Afghanistan and Iraq, whose 
interviewing techniques left two suspects dead from 'blunt force injuries' in Bagram Airbase (Gumbel, 2003), the systemic abuse and torture of prisoners at Abu Ghraib prison in Baghdad (Goldenberg, 2004), or the assault and killing of prisoners in Basra (Associated Press, 2005). What emerges from this can be said to represent an urban geography of interiors that contain what has physically and historically been displaced from the public regions of cities: an inner domain of institutional executions and sanctioned torture whose very distance from the collective eye render them possible within a society that claims abhorrence for all inhumane and cruel acts of interrogation and punishment. It is only when the obscurity of such practices conducted in the name of society is breached, that complacency is compromised and outrage begins.

And yet what supports this strange sense of denial that protects the communities of the West from seeing themselves as they really are, of what human society has always been capable, is in part bolstered by a contemporary and distorted historical conception of the urban square as a site that personifies all that is politically, socially and culturally civilized and moral; the proof that ours is an age that has progressed beyond what is contemptible and barbaric. This is supported, moreover, through another mode of historical dislocation that looks not to the present, but the historical figure of the Inquisition as symbolic of the cruellest and most inhumane episode of judicial interrogation. The Inquisition was not, however, the natural outcome of some less rational age, its use was seldom arbitrary, nor was it designed to sate the appetites of psychopaths. Rather, it was directed at obtaining the same ends as our own contemporary methods of physical and psychological persuasion: confession. The Inquisition was a precisely calibrated method of legal inquiry for which a large amount of evidence was required before an individual could be subjected to the implements of judicial torture. The sighting of the instruments comprised the first stage of this process, which in the case of children or persons over the age of seventy, did not go beyond this point (Foucault, 1991, p. 40). As a vehicle of investigation it belonged to a rational system of codes and procedures that, as put by Hirst and Woolley (1982, p. 224), 'though we shudder at the idea of torture, we accept standards of proof in respect to serious crimes which would horrify a Renaissance lawyer'. The relocation of judicial torture and 
capital punishment towards the interior regions of corrective establishments did not signal any advance of 'civilized' values so much as a slide between differing fields of rationality, on views of life and death, societal forms of pleasure and offence and what, from an urban and social perspective, could be visibly exposed or hidden out of sight and mind.

On the other hand, for the West, ours is an age that is not quite so distant or as free of those collective pageants of human torture and punishment of as we might like to believe. The last public guillotining in France took place in 1939 (Spierenburg, p. 198). But it was predominantly in the Southern States of the USA during the last years of the nineteenth century and first decades of the twentieth that saw a return to the high drama of public torture, execution and burning. The victims in each case were Afro-Americans accused, but seldom found guilty of any crime. Their fate, as with the 1895 lynching of Henry Hilliard in Tyler, Texas, would include being tied to a stake and burnt alive. What was left of Hilliard's body was then distributed as mementoes amongst the 5000 white citizens who attended the spectacle (Bruce, 1901). In 1899 in Atlanta, Georgia, Samuel Hose, accused of murder and rape, was tied to a stake and before being burned alive, had both his ears cut off and other parts of his anatomy mutilated. Again, the bones, flesh and stake were removed as souvenirs (Wells-Barnett, 1899). During the year of 1900, up to 117 Afro-American citizens were dispatched through various collective rituals of shooting, hanging and burning. In many instances, as in the case of Samuel Hose, the time and location of these pseudo-punitive ceremonies was advertised in local newspapers and special trains laid on to transport eager spectators. But like the punitive dramas of Savonarola and Damiens that they echo, such displays form no part of any contemporary or historical vision of activities particular to the public spaces of cities or towns. This was a situation encountered by Robert Worth (1998) who, when recently investigating the circumstances surrounding a lynching in Coatesville, Pennsylvania in 1911, discovered an entire community in denial around the past events which sentenced Zachariah Walker to be burned alive before the 'good' citizens of the town. 
It is this same sense of denial that continues to underscore a sanitized historical reading of the urban square, incapable of being conceived as anything other than a product of socially beneficial, humane and libertarian forces. Ours is an age that has come to perceive itself as both the proud possessor and inheritor of urban spaces that encompass and express the higher values of the community. This is a legacy that still looks to the 'golden' era of Kant's public sphere of free, rational and informed debate (1990, p. 59), and its loss in the world of today through causes that speak of consumerism (Habermas, 1992, p. 162), or capitalism and secularism (Sennett, 1987, p. 47). Here we are still confronted by historical and contemporary analyses of urban space, such as Madanipour's Public and Private Spaces of the City (2003), that unfold without mention of the public executions, torture or racial lynching that functioned within the heart of a communities, towns and cities public terrains. It was, nevertheless, only after the streets and squares of the urban realms in the West were cleansed of their less desirable practices, such as punitive ceremonies, that the construction of such a perspective could eventuate and with it, a conception that transformed our current ideas, meanings and uses of the urban square into an illusory historical narrative starved of critical engagement or context.

\section{Conclusion}

For urban history, the task should ever be to discover what was particular to the orders of rationality and reality that informed each preceding eras own conditions of urban possibility and experience. But subsuming the past to the illusory unity of trans-historical norms and meta-narratives, or imposing upon it the meanings, values and concerns of the present will never achieve such an outcome. Nor will such a goal be realized by simply erasing from sight what offends contemporary sensibility or ideologically contrived conceptions of the past. To attain any degree of critical and contextual historical interpretation requires suspending any metaphysical sense of universality and continuity, or conceiving of history as a space of the same. What also must be rescinded is the pernicious will to politically, socially or morally judge the past in the terms of the present or, as stated by Nietzsche in relation to the inquisition and burning of Miguel Serveto in 1553, "When considering 
earlier periods of history one must take care not to fall into an unjust condemnation of them. The injustice involved in slavery, the cruelty involved in the subjugation of persons and nations is not to be measured by our own standards” (1994, p. 54).

It was these questions of history that were explored during this discussion on the historical subject of the urban square, the practice of public executions, and a tradition that has sought to restrain the visibility of such rituals via an idealized reading of urban space and the social, moral and political life of the public square. The lesson of these sorrowful ceremonies of organized human extinction, however, as identified over the last century by such as Nietzsche, Kafka, Camus and Foucault, is not the loss of some essential drama of community celebration, but a tendency to reduce the scope of the human and social condition down to an impoverished caricature. When applied to the historical subject of the urban square, this same regressive stance has left in its wake an overly simplistic and indeed insipid account of urban existence that weakens any credible historical understanding of the more complex social and spatial relations undertaken within those past urban arenas of public appearance. It is also by allowing this incomplete and distorted historical vision to prevail as the exemplar by which to test the contemporary status of the public square, that deflects our gaze away from what is specific to the social and urban realities of today's streets and squares and from that other hidden geography of interiorized interrogation, justice and punishment. It is via the exchange of historical rigour for nostalgia and wish fulfilment that we continue to escape from what, in a human and urban sense, we were and are, of the diverse nature and types of activity contained within the urban landscape of cities, and in what way its physical characteristics enhanced the various uses to which it was put. In the end, such shortcomings can only be overcome by rethinking what was actual to and implied by the historical conditions of the urban realm, which in the case of the public square and capital punishment would expose a time when individuals could declare 'O comrade, what times those were!' 


\section{References}

Arendt, H. (1958) The Human Condition. Chicago: Chicago UP.

Aries, P. (1981) The Hour of Our Death. H.Weaver (Trans), New York: Alfred A Knopf Inc.

Basson, S. (1998) The Public gaze: An Historical Analysis of Public and Private Space. Unpublished Thesis, University of Western Australia.

Bentham, J. (1882) The Theory of Legislation. R.Hildreth (Trans), London: Trubner \& Co.

“Botticelli”. (1993) The Great Artists: Their Lives, works and Inspiration. 29, pp. 897-928.

Bourdieu, P. (1995) The Field of Cultural Production. Cambridge: Polity Press.

Bruce, J E. (1901) The Blood red record, in: African American Perspectives: Pamphlets

from the Daniel A.P Murray Collection, 1818-1907. Washington: Library of Congress.

Camus, A. (1963) Resistance, Rebellion and Death. J.O'Brian (Trans), London: Hamish Hamilton.

Camus, A. (2000) The Myth of Sisyphus. J.O’Brien (Trans), London: Penguin Books.

De Baecque, A. (2001) Glory and Terror: Seven Deaths Under the French Revolution. C.Mandell (Trans), New York: Routledge.

Diderot, D. (1967) The Encyclopedia: Selections. S.Gendzier (Ed. Trans), New York: Harper \& Row. 
Elias, N. (1978) The Civilizing Process. E.Jephcott (Trans), New York: Urizen Books.

Foucault, M. (1985) Other Spaces: The Principles of Heterotopia, Lotus International, 4849, pp. 9-17.

Foucault, M. (1991) Discipline and Punish: The Birth of the Prison. A.Sheridan (Trans), Harmondsworth: Penguin.

Goldenberg, S. (2004) Soldier Says Abu Ghraib Interrogators Told Him to Stage Mock

Electrocution, Guardian Newspaper, $21^{\text {st }}$ October, London.

Gross, H. (1990) Rome in the age of Enlightenment: The Post-Tridentine Syndrome and the Ancien Regime, Cambridge: Cambridge UP.

Gumbel, A. (2003) America Admits Suspects Died in Interrogations, Independent Newspaper, $7^{\text {th }}$ March, London.

Habermas, J. (1992) The structural Transformation of the Public Sphere: An Inquiry into a Category of Bourgeois Society. T.Burger \& F.Lawrence (Trans), Cambridge: Polity Press.

Hirst, P \& Woolley, P. (1982) Social Relations and Human Attributes. London: Tavistock.

Jencks, C \& Valentine, M. (1987) The Architecture of Democracy: The Hidden Tradition, Architectural Design. 57.9-10, pp. 9-25.

Kafka, F. (1995) The Judgement and the Penal Colony. Harmondsworth: Penguin.

Kant, I. (1990) An Answer to the Question: What is Enlightenment?, in: H.Reiss (Ed) Kant's Political Writings, pp. 54-60, Cambridge: Cambridge UP. 
Madanipour, A. (2003) Public and Private Spaces of the City. London: Routledge.

Nietzsche, F. (1994) Human, All Too Human. M.Faber \& S.Lehmann (Trans), London:

Penguin Books.

Paine, T. (1996) Rights of Man. Hertfordshire: Wordsworth Editions Ltd.

Pascal, B. (1989) Pensees, in: R.Popkin (Ed) Pascal: Selections, pp. 195-264, New York: Macmillan.

Press Association (2005) UK Soldiers Face Iraq War Crimes Trial, Guardian Newspaper, $19^{\text {th }}$ July, London.

Rousseau, J J. (1968) The Social Contract and Discourses. G.D.H.Cole (Trans), London: J M Dent and Sons.

Rowe, C \& Koetter, F. (1976) Collage City. Cambridge, Mass: MIT P.

Sennett, R. (1987) The Public Domain, in: N.Glazer \& M.Lilla (Ed.) The Public Face of Architecture, pp. 26-47, New York: Free Press.

Sennett, R. (1993) The Fall of Public Man. London: Faber \& Faber.

Sitte, C. (1986) Camillo Sitte: The Birth of Modern City Planning. G.R.Collins \& C.Crasemann (Ed. Trans), New York: Rizzoli.

Spierenburg, P. (1984) The Spectacle of Suffering: Executions and the evolution of Repression - From a Preindustrial Metropolis to the European Experience. Cambridge: Cambridge UP. 
Villari, P. (1969) Life and Times of Giralomo Savonarola: Vol II. New York: Haskell House Publishers.

Wells-Barnett, I B. (1899) Lynch Law in Georgia, in: African American Perspectives:

Pamphlets from the Daniel A.P Murray Collection, 1818-1907. Washington: Library of Congress.

Winner, L. (1992) Silicon Valley Mystery House, in: M.Sorkin (Ed.) Variations on a Theme Park: The New American City and the End of Public Space, pp. 31-60, New York: Hill and Wang.

Wood, J. (1969) A Description of Bath. Bath: Kingsmead Reprints.

Worth, R.F. (1998) The legacy of a Lynching: Coatsville, Pennsylvania 1911, The American Scholar, 67, pp. 65-77. 